W niniejszym dziale zamieszczamy wybrane streszczenia rozpraw doktorskich dotyczących chorób nowotworowych, obronionych przed Radą Naukową Centrum Onkologii —-Instytutu im. M. Skłodowskiej-Curie oraz w innych ośrodkach naukowych w kraju. Zachęcamy Doktorantów do kontaktu z Redakcją Nowotworów i nadsyłanie propozycji na adres: redakcja@coi.waw.pl.

Inną możliwością publikacji doktoratu, do której również zachęcamy, jest przedstawienie go w obszerniejszej formie — w postaci klasycznej pracy oryginalnej.

\title{
Porównanie dwóch sposobów przyspieszonej radioterapii chorych na raka głowy i szyi w odniesieniu do radiobiologii guza nowotworowego i zdrowych tkanek
}

\author{
Marcin Hutnik
}

Promotor: prof. dr hab. n. med. Krzysztof Składowski

Recenzenci: prof. dr hab. n. med. Bogusław Maciejewski, dr hab. n. med. Piotr Milecki

Data obrony: 24 września 2014 r.

Celem pracy jest ocena wyników dwóch różnych sposobów przyspieszonego frakcjonowania dawki promieniowania w ramach kontrolowanego badania CAIR-2. Ponadto dodatkowym celem pracy jest ustalenie, czy przerwa obejmująca sobotę i niedzielę wpływa na skuteczność przyspieszonej radioterapii u chorych na płaskonabłonkowego raka regionu głowy i szyi.

Badanie przeprowadzono w I Klinice Radioterapii w Centrum Onkologii w Gliwicach w latach 1996-2006. Do badania włączono 345 kolejnych chorych na płaskonabłonkowego raka jamy ustnej, środkowego lub dolnego piętra gardła oraz górnego piętra krtani, u których radioterapia była wyłączną (definitywną) metodą leczenia. Przyjęto następujące kryteria kwalifikacji do badania: wiek do 80 roku życia włącznie; zaawansowanie cT2-4 N0-1 M0; ogólny stan sprawności chorego 0-2 według klasyfikacji WHO; brak współistniejącego lub uprzednio leczonego innego nowotworu; świadoma zgoda na udział w badaniu. Jednocześnie ustalono następujące kryteria wyłączenia: spadek masy ciała powyżej 10\% w ciągu $\geq 3$ miesięcy przed leczeniem; radiologicznie potwierdzone naciekanie żuchwy lub chrząstki tarczowatej; odmowa udziału w badaniu. W sposób losowy pacjentów przydzielano do grupy badanej CB (concomitant boost; 172 chorych) lub kontrolnej CAIR (continuous accelerated irradiation; 173 chorych).

W obu grupach stosowano przyspieszone napromienianie dawką frakcyjną 1,8 Gy. Wielkość całkowitej (leczącej) dawki promieniowania zależała od zaawansowania raka i wahała się w przedziale od 66,6 Gy w 36 frakcjach w czasie 36 dni (dla przypadków T2 N0 M0) do 72,0 Gy w 40 frakcjach w czasie 40 dni (dla przypadków T3-4 N0-1 M0). W grupie CAIR dawkę frakcyjną podawano regularnie co 24 godziny przez 7 dni w tygodniu (w tym w soboty i niedziele). W grupie CB dawkę frakcyjną podawano przez 5 dni w tygodniu (z wyłączeniem sobót i niedziel); łącznie w ciągu tygodnia podawano 7 dawek, bowiem we wtorki i piątki napromieniano chorych 2 razy dzienne. Całkowity czas leczenia, dawka całkowita i liczba frakcji były w obu grupach takie same dla przypadków o tożsamym zaawansowaniu. Jedynym parametrem różniącym schematy przyspieszonego napromieniania użyte w obu ramionach badania był rytm podawania dawki. W latach 1996-1997 chorych leczono promieniami gamma ${ }^{60} \mathrm{Co}$, a w latach późniejszych promieniowaniem fotonowym o energii $6 \mathrm{MV}$, generowanym w przyspieszaczu liniowym z wykorzystaniem techniki 3D-CRT i kolimatora MLC (76\% chorych). W planowaniu radioterapii u każdego chorego wyznaczano następujące objętości: 1) makroskopową objętość guza (GTV), obejmującą guz pierwotny $\left(G_{1}\right)$ i ewentualnie przerzutowo zmienione węzły chłonne szyi $\left(G_{T} V_{2}\right)$; indywidualnie wyznaczaną kliniczną objętość tarczową (CTV), która obejmowała dodatkowo margines tkanek zdrowych zagrożonych subklinicznym naciekaniem lub migracją

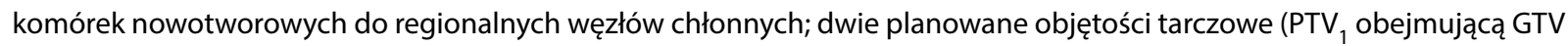
wraz z dodatkowym 0,5 cm marginesem, PTV 2 obejmującą PTV1 i CTV wraz z odpowiednim marginesem); zakładane mar- 
ginesy uwzględniały ruchomość oddechową i możliwość przesunięć chorego pod aparatem terapeutycznym. Pola "duże” obejmujące PTV 2 napromieniano w obu grupach (CB i CAIR) codziennie od poniedziałku do piątku, natomiast pola "małe” obejmujące PTV ${ }_{1}$ napromieniano w każdą sobotę i w niedzielę w grupie CAIR oraz w każdy wtorek i piątek po upływie 6-8 godzin jako drugą frakcję w grupie CB. Dla oceny skuteczności obu metod napromieniania przyjęto następujące kryteria: miejscowe wyjałowienie guza pierwotnego i przerzutu w szyjnym węźle chłonnym (locoregional control — LRC), przeżycie całkowite (overall survival — OS), a także częstość wznów miejscowych i niewyleczeń miejscowych (wszystkie parametry dla 5 lat). Oceniano również nasilenie oraz częstość ostrych i późnych odczynów popromiennych.

W grupie CAIR uzyskano ogółem 63\% i 60\% aktualizowanych 5- i 10-letnich wyleczeń lokoregionalnych oraz 40\% i 25\% 5- i 10-letnich przeżyć całkowitych w porównaniu z odpowiednio 65\% i 60\% oraz 44\% i 25\% w grupie CB (test log-rank, $p=0,96$ i $p=0,99)$. Dla całego okresu obserwacji wznowę guza pierwotnego stwierdzono u 32 spośród 151 chorych (21\%) z całkowitą regresją w grupie CAIR i u 24 spośród 144 chorych (17\%) w grupie CB. Niewyleczenie guza pierwotnego stwierdzono u 21 chorych (12\%) z grupy CAIR i u 27 chorych (16\%) z grupy CB $(p=0,34)$. W czasie pierwszych 12 miesięcy obserwacji wznowę guza pierwotnego stwierdzono u 13 spośród 151 chorych (9\%) z całkowitą regresją w grupie CAIR i u 11 spośród 144 chorych (8\%) w grupie CB. W odniesieniu do przerzutów do regionalnych węzłów chłonnych szyjnych niewyleczenie odnotowano u 6 chorych (3\%) z grupy CAIR i u 5 (3\%) z grupy CB, natomiast w okresie pierwszych 12 miesięcy obserwacji wznowa wystąpiła u 3 spośród 166 chorych (2\%) z całkowitą regresją w grupie CAIR i u 5 spośród 166 chorych (3\%) w grupie CB. W grupie CB wznowy miejscowe ujawniały się równomiernie w kolejnych miesiącach pierwszego roku obserwacji. W grupie CAIR wznowy miejscowe ujawniły się w miesiącach 6-8 (45\%) oraz 11-12 (55\%), natomiast w miesiącach 9-10 nie odnotowano żadnej wznowy miejscowej raka. Dla grupy kontrolnej CAIR parametr $\mathrm{T}_{50}$ (czas ujawnienia się $50 \%$ wznów miejscowych) wyniósł 14 miesięcy, a dla grupy badanej CB 12,4 miesiąca. Rozlane zapalenie błony śluzowej (w stopniu 3 lub 4 wg EORTC/RTOG) było najczęstszym ostrym odczynem popromiennym — występowało u 86\% pacjentów z ramienia CB i 89\% pacjentów z ramienia CAIR. Czas trwania rozlanego zapalenia błony śluzowej wynosił $29 \pm 3$ dni w grupie CB i $31 \pm 4$ dni w grupie CAIR. Jedynie w okresie pierwszych dwóch tygodni odnotowano istotne statystycznie różnice pomiędzy zastosowanymi metodami leczenia - ostry odczyn popromienny w stopniu 3 i 4 odnotowano u 54 chorych (32\%) z ramienia CB i u 82 pacjentów $(48 \%)$ z ramienia CAIR $(p=0,028)$. Stosowane $w$ badaniu schematy radioterapii okazały się bezpieczne w odniesieniu do ryzyka rozwoju późnych odczynów popromiennych. Prawdopodobieństwo przeżycia wolnego od późnych odczynów popromiennych w stopniu 3-4 wg EORTC/RTOG wyniosło dla obu grup 95\% w 5-letnim okresie obserwacji. Analiza wyników leczenia wykonana w podgrupach chorych uporządkowanych według kryteriów opisujących pacjenta, nowotwór i sposób napromieniania nie wykazała istotnych różnic wynikających ze skuteczności badanych metod leczenia. Istotnie wyższy odsetek 5-letnich przeżyć całkowitych stwierdzono jedynie w podgrupie chorych w wieku 41-50 lat w grupie CAIR oraz u pacjentów z niskim wyjściowym stężeniem hemoglobiny i u chorych z rozpoznaniem raka cT2N1M0 napromienianych wg schematu CB.

Wyniki analizy wieloczynnikowej wykazały, że czynnikami prognostycznymi dla przeżycia całkowitego są wyjściowe stężenie hemoglobiny i palenie tytoniu. Jeśli przed leczeniem stężenie $\mathrm{Hb}$ przekraczało $13 \mathrm{~g} / \mathrm{dl}$, to ryzyko zgonu było mniejsze o 37\%. Fakt palenia tytoniu (w czasie leczenia i w przeszłości) dwukrotnie zwiększał ryzyko zgonu. Stwierdzono również, że czynnikiem prognostycznym dla wyleczenia lokoregionalnego raka jest zaawansowanie guza pierwotnego. Szansa lokoregionalnego wyleczenia spadała o 50\% w grupach raka jamy ustnej, gardła lub krtani w stopniu T3 lub T4 w porównaniu z T2.

Wyniki przeprowadzonej analizy wskazują, że przyspieszona radioterapia z zastosowaniem takiej samej całkowitej dawki promieniowania i wielkości dawek frakcyjnych oraz w takim samym całkowitym czasie leczenia, ale podawana w różnym rytmie frakcjonowania (z przerwą lub bez przerwy obejmującej sobotę i niedzielę), nie różni się skutecznością w leczeniu chorych na płaskonabłonkowego raka regionu głowy i szyi. Ponadto różnica w efektach biologicznych wyzwalanych przez napromienianie według schematu CAIR (bez przerwy obejmującej sobotę i niedzielę) i CB (z przerwą) jest najprawdopodobniej wynikiem przyspieszonej repopulacji komórek raka i komórek zarodziowych błony śluzowej w trakcie przerw w napromienianiu i przejawia się jedynie w tempie ujawniania wznów miejscowych raka oraz w nasileniu ostrego odczynu popromiennego podczas pierwszych dwóch tygodni leczenia. Jest to zjawisko bez znaczenia klinicznego. Wyniki badania CAIR-2 wskazują, że dla uzyskania znacznego zysku terapeutycznego konieczna jest dyscyplina czasowa, tj. nieprzekraczanie 5-6 tygodni całkowitego czasu leczenia. Jednocześnie stwierdzono, że nie ma potrzeby ciągłego napromieniania przez 7 dni w tygodniu, ponieważ zachowanie dotychczasowego standardowego rytmu leczenia przez 5 dni w tygodniu jest równie skuteczne.

Dr n. med. Marcin Hutnik

I Klinika Radioterapii i Chemioterapii Centrum Onkologii — Instytut im. Marii Skłodowskiej-Curie Oddział w Gliwicach

Wybrzeże Armii Krajowej 15, 44-100 Gliwice e-mail:marcinhutnik@interia.pl 